\title{
Retraction Note to: Revisiting the Evolution of IR Spectra of CO Adsorbed on Au Nanoparticles Supported on Non-reducible Supports
}

\author{
Ranin Atwi ${ }^{1} \cdot$ Taha Elgayyar $^{1} \cdot$ Francisco J. Cadete Santos Aires $^{1}$ (D) - Alain Tuel ${ }^{1}$ (I) $\cdot$ Frederic C. Meunier $^{1}$ (I)
}

Accepted: 21 June 2021 / Published online: 28 June 2021

๑) Springer Science+Business Media, LLC, part of Springer Nature 2021

\section{Retraction to: Topics in Catalysis (2020) 63:1596-1605 https://doi.org/10.1007/ s11244-020-01372-2}

The authors have retracted this Article because, after reexamination, some of the results were found to be no longer reliable.

In their article, the authors related the temporal evolution of IR bands of $\mathrm{CO}$ adsorbed on Au to a hypothetical reconstruction process. A recent work [1] pointed out that a similar effect could be induced by the presence of nickel through contamination by $\mathrm{Ni}(\mathrm{CO})_{4}$.

The authors re-examined their data and noted that up to 5 ppm of $\mathrm{Ni}(\mathrm{CO})_{4}$ were unexpectedly observed in the effluent gases of the diffuse reflectance FT-IR (DRIFTS) cell that had not previously been noticed. $\mathrm{No} \mathrm{Ni}(\mathrm{CO})_{4}$ was detected in the high-purity $5 \% \mathrm{CO} / \mathrm{He}$ from Air Liquide S.A., which had been further purified using a liquid $\mathrm{N}_{2}$ trap. $\mathrm{Ni}(\mathrm{CO})_{4}$ could also not be detected when $\mathrm{CO}$ had been co-fed with $\mathrm{O}_{2}$ or if the cell reactor had not previously been raised to $300{ }^{\circ} \mathrm{C}$ under $\mathrm{H}_{2}$. The authors conclude that part of the cell (from Harrick) had been corroded, probably by $\mathrm{NO}_{\mathrm{x}}$ used during the same period, and reacted with $\mathrm{CO}$ to form $\mathrm{Ni}(\mathrm{CO})_{4}$ in situ, only when the nickel present had been reduced to the metallic state.
The original article can be found online at https://doi.org/10.1007/ s11244-020-01372-2.

Frederic C. Meunier

fcm@ircelyon.univ-lyon1.fr

1 Univ Lyon, Université Claude Bernard Lyon 1, CNRS, IRCELYON, 2 Av. Albert Einstein, 69626 Villeurbanne, France
The authors attempted to reproduce the experiment reported in this Article over the same materials using a new Harrick cell and they could no longer observe the major $\mathrm{Au}-\mathrm{CO}$ band shift from ca. 2106-2110 $\mathrm{cm}^{-1}$ down to $2070-2060 \mathrm{~cm}^{-1}$ with concomitant several-fold intensity increase that occurred in less than 10 min (see Figs. 3.A and 6.A). By contrast, they found that the band position and intensity remain constant over 60 min (Fig. 1).

The authors therefore conclude that the spectral evolutions reported in this Article were likely not the result of any restructuring, but rather $\mathrm{Ni}(\mathrm{CO})_{4}$ contamination and deposition of $\mathrm{Ni}$ over the $\mathrm{Au}$ nanoparticles, leading to $\mathrm{Ni}-\mathrm{CO}$ species being formed and replacing Au sites.

The authors note that a sample of Au encapsulated in a silicalite-1 zeolite that had been exposed to $\mathrm{Ni}(\mathrm{CO})_{4}$ did not show this band shift, indicating that $\mathrm{Ni}(\mathrm{CO})_{4}$ could not enter the pores of silicalite- 1 at $50{ }^{\circ} \mathrm{C}$.

The authors hope that their experience will raise more awareness of the potential pitfalls associated with using $\mathrm{CO}$ at low temperatures on corroded steel cells.

All authors agree with this retraction. 
(A)

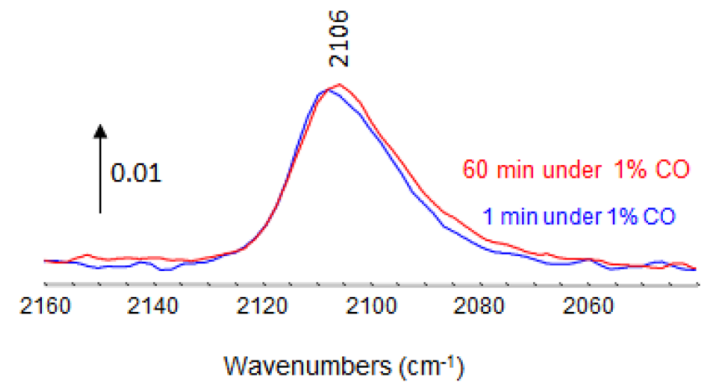

(B)

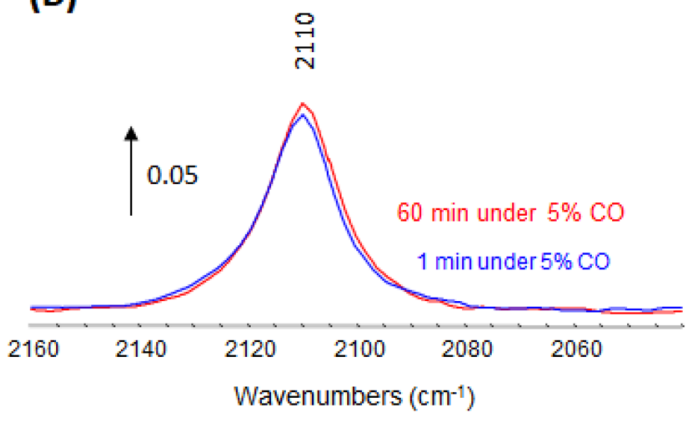

Fig. 1 In situ DRIFTS spectra at $50{ }^{\circ} \mathrm{C}$ under $1 \%$ or $5 \% \mathrm{CO} / \mathrm{He}$ observed over A $2.1 \%$ Au/alumina and B $1 \%$ Au/silica. The samples were prereduced in situ with $\mathrm{H}_{2}$ at $300{ }^{\circ} \mathrm{C}$

\section{Reference}

1. Yao Y, Chen L, Mao X, Yang Y, Chen J, Zhou L (2021) J Phys Chem C 125:8606-8619

Publisher's Note Springer Nature remains neutral with regard to jurisdictional claims in published maps and institutional affiliations. 